DOI: $10.19195 / 0524-4544.327 .5$

\author{
WOJCIECH JAKIMOWICZ \\ ORCID: 0000-0001-6999-4574 \\ Uniwersytet Jagielloński \\ wojciech.jakimowicz@uj.edu.pl
}

\title{
Zewnętrzne czynności materialno-techniczne administracji publicznej
}

\begin{abstract}
Abstrakt: Rozważania w ramach artykułu zostały poświęcone czynnościom materialno-technicznym zewnętrznym, które w odróżnieniu od czynności materialno-technicznych wewnętrznych skierowane są do adresatów niepodporządkowanych ani służbowo, ani organizacyjnie. Mogą to być czynności, które - jako formy działania - mają charakter samodzielny, jak i te, które w jakimś stopniu wiążą się z innymi formami działania stanowiąc np. „dopełnienie” działań bezpośrednio-zobowiązujących poprzez wyzwolenie mocy obowiązującej norm wynikających z tego rodzaju działań.
\end{abstract}

Słowa kluczowe: czynności materialno-techniczne, formy działania administracji, czynności zewnętrzne.

\section{I}

Administracja publiczna wykonuje swoje funkcje i zadania na rozmaitych obszarach życia społecznego. Czyni to również w rozmaity sposób. Oczywistość tych stwierdzeń można by uznać za niewymagającą ich odnotowywania, gdyby nie spostrzeżenie, że inspirowała ona naukę prawa administracyjnego, a z czasem również prawodawcę, do podejmowania prób sklasyfikowania i scharakteryzowania różnych przejawów zachowań organów wykonujących administrację publiczną. Wypracowane w nauce klasyfikacje form działania administracji miały — jak się z czasem okazało - nie tylko znaczenie teoretyczne, lecz wpłynęły również na treść regulacji prawnych dotyczących przedmiotu kontroli sądowoadministracyjnej. Obecnie w art. $3 \S 2$ pkt 4 Ustawy z dnia 30 sierpnia 2002 roku Prawo o postępowaniu przed sądami administracyjnymi ${ }^{1}$ znajduje się regulacja, według

1 Ustawa z dnia 30 sierpnia 2002 r. Prawo o postępowaniu przed sądami administracyjnymi (tekst jedn. Dz.U. z 2018 r. poz. 1302; dalej: p.p.s.a.).

Prawo 327, 2019

(C) for this edition by CNS 
której kontrola działalności administracji publicznej przez sądy administracyjne obejmuje orzekanie w sprawach skarg na inne niż określone w pkt 1-3 akty lub czynności z zakresu administracji publicznej dotyczące uprawnień lub obowiązków wynikających z przepisów prawa.

Prezentowane opracowanie nawiązuje do klasycznego już w polskiej doktrynie prawnej podziału form działania administracji publicznej rozumianych jako „określone przepisem prawa typy konkretnych czynności organu administracyjnego"2 na czynności prawne oraz czynności faktyczne i dotyczy niektórych czynności wchodzących w skład drugiej z wyżej wymienionych grup form działania. Jego celem jest bowiem analiza kategorii tych czynności faktycznych organów administracji publicznej, które stanowią formę ingerencji w sferę praw i obowiązków podmiotów stojących na zewnątrz administracji, podjęcie próby uchwycenia ich istoty, a w konsekwencji udzielenie odpowiedzi na pytanie o adekwatność ochrony sądowoadministracyjnej adresatów tego rodzaju czynności.

Rozważania będą zatem dotyczyły czynności materialno-technicznych zewnętrznych, które, w odróżnieniu od czynności materialno-technicznych wewnętrznych, skierowane są do adresatów niepodporządkowanych ani służbowo, ani organizacyjnie ${ }^{3}$. Mogą to być czynności, które - jako formy działania mają charakter samodzielny, jak i te, które w jakimś stopniu wiążą się z innymi formami działania, stanowiąc np. „dopełnienie” działań bezpośrednio zobowiązujących poprzez wyzwolenie mocy obowiązującej norm wynikających z tego rodzaju działań ${ }^{4}$. Nie chodzi przy tym o takie czynności materialno-techniczne, które mają charakter instrumentalny wobec działań prawnych przez to, że wiążą się z techniką administrowania. Poza zakresem analizy pozostają także inne przejawy działań faktycznych administracji publicznej, takie jak tzw. działania społeczno-organizatorskie oraz zaświadczenia.

\section{II}

Próbę ustalenia stanowiska nauki na temat cech charakteryzujących zewnętrzne czynności faktyczne organów administracji publicznej należy rozpocząć od nawiązania do poglądów M. Zimmermanna, który w okresie powojennym był prekursorem w zakresie badań nad formami działania administracji publicznej.

2 J. Starościak, Prawne formy działania administracji, Warszawa 1957, s. 14.

3 Zob. M. Wierzbowski, A. Wiktorowska, Czynności faktyczne, [w:] Polskie prawo administracyjne, red. J. Służewski, Warszawa 1995, s. 216. Zob. też M. Masternak, Kontrola czynności materialno-technicznych administracji publicznej przez sąd administracyjny, [w:] Prawo do dobrej administracji, red. Z. Niewiadomski, Z. Cieślak, Warszawa 2003, s. 131; M. Stahl, Czynności materialno-techniczne, [w:] Prawo administracyjne. Pojęcia, instytucje, zasady w teorii i orzecznictwie, red. M. Stahl, Warszawa 2016, s. 504.

4 J. Zimmermann, Prawo administracyjne, Warszawa 2018, s. 442. 
M. Zimmermann, charakteryzując formy działania administracji, wskazywał, że

wszystkie działania administracji państwowej muszą się opierać na podstawie prawnej w tym sensie, że dana czynność musi stanowić cząstkę realizacji zadań, które prawo danemu organowi przydziela, musi być przewidziana i regulowana chociażby najogólniej przez przepisy prawne. Tym samym powstają różne kryteria oceny ich prawidłowości i z punktu widzenia tych kryteriów przede wszystkim zaś z punktu widzenia istnienia dostatecznych podstaw prawnych i zgodności ich działania z tymi podstawami, mogą one stać się przedmiotem kontroli ${ }^{5}$.

Stanowisko to wymaga zaakcentowania i zaakceptowania, bo wyraża fundamentalne założenia każdej analizy administracyjnoprawnej, zgodnie z którymi jakikolwiek przejaw działalności administracji publicznej musi znajdować swoją podstawę prawną i powinien podlegać kontroli.

Należy zatem od razu przyjąć, że tak jak każda aktywność administracji wymaga upoważnienia ustawowego, tak również dokonywanie zewnętrznych czynności materialno-technicznych jest dopuszczalne wtedy, gdy istnieje ku temu norma kompetencyjna. Ponadto — skoro czynności te mają charakter zewnętrzny przesłanki ich dokonywania muszą być określone w normach prawa materialnego, które stanowią ich podstawy. Podstawą zewnętrznych czynności materialno-technicznych może być również norma prawa materialnego zindywidualizowana i skonkretyzowana $\mathrm{w}$ formie indywidualnego aktu administracyjnego ${ }^{6}$.

W ramach działalności administracji publicznej M. Zimmermann wyróżniał jej działania faktyczne, które definiował jako „wszelkie te działania, które nie są skierowane na wywoływanie bezpośrednio określonych skutków prawnych"”, zaliczając do nich różnego rodzaju czynności techniczne, pomocnicze, niezbędne dla prawidłowego funkcjonowania administracji, podkreślając, że „,niekiedy przeprowadzenie granicy między czynnością techniczną a czynnością prawną jest sprawą trudną i granicę taką nie zawsze da się ostro przeprowadzić" 8 i wskazując np. na tzw. poświadczenia. Jednocześnie definiował akty administracyjne jako regulowane przez prawo administracyjne czynności prawne administracji polegające na „objawieniu woli przez organ państwowy, działający w zakresie administracji państwowej w celu wywołania określonych skutków prawnych, a więc utworzenia, zmiany lub zniesienia stosunków prawnych"9.

Dostrzeżona przez M. Zimmermanna podstawowa trudność w definiowaniu zewnętrznych czynności materialno-technicznych polegająca na uchwyceniu granicy między nimi a aktami administracyjnymi była później wielokrotnie sygnalizowana w doktrynie. Należy jednak zauważyć, że wyróżnienie przez tego Autora elementów „woli” i elementów „techniki” w spojrzeniu na akty i czynności sta-

${ }^{5}$ M. Zimmermann, Formy działania administracji państwowej. Akt administracyjny, [w:] M. Jaroszyński, M. Zimmermann, W. Brzeziński, Polskie prawo administracyjne. Czesść ogólna, Warszawa 1956, s. 320.

6 Zob. M. Wierzbowski, A. Wiktorowska, op. cit., s. 215.

7 M. Zimmermann, op. cit., s. 321.

8 Ibidem.

9 Ibidem, s. 322. 
nowiło bez wątpienia istotny drogowskaz w poszukiwaniu odpowiedzi na pytanie o istotę zewnętrznych czynności materialno-technicznych.

Podkreślenia przy tym wymaga, że pojęcie aktu administracyjnego M. Zimmermann wiązał — również przy uwzględnieniu uwarunkowań historycznych z regulacją i bezpośrednią ochroną praw podmiotowych jednostek, podnosząc, że konstruowanie zewnętrznego aktu administracyjnego było potrzebne

dla umożliwienia i ułatwienia ochrony praw indywidualnych przez wprowadzenie procedury wzorowanej na postępowaniu sądowym i zawierającej gwarancje procesowe, wzorowane na gwarancjach procesu sądowego, oraz przez wprowadzenie instytucji sądownictwa administracyjnego ${ }^{10}$.

Myśl tę wyrażoną na tle rozważań o formach działania administracji rozumiem w ten sposób, że potrzeba teoretycznej konstrukcji aktu administracyjnego znajdująca uzasadnienie w wyraźnie akcentowanej przez M. Zimmermanna konieczności zapewnienia ochrony praw podmiotowych jednostki miała wymiar ogólniejszy, nie stanowiła wyłącznie rezultatów refleksji naukowej, lecz była również w znacznym stopniu apelem o ochronę (zwłaszcza sądowoadministracyjną) „,przed” administracją działającą w rozmaitych formach.

Przekonują o tym wskazane przez M. Zimmermanna kryteria odróżniania czynności faktycznych administracji publicznej od aktów administracyjnych, takie jak: kryterium pośredniości (bezpośredniości) wywoływania skutków prawnych (ale jednak skutków prawnych), kryterium związków z regulacją i ochroną praw podmiotowych jednostek oraz kryterium sformalizowanej, gwarancyjnej procedury, zaakceptowane zresztą później w doktrynie prawa administracyjnego i orzecznictwie sądowoadministracyjnym.

\section{III}

Obecnie J. Zimmermann wskazuje, że każde działanie, które w przeciwieństwie do czynności prawnych nie zmierza do ustanowienia, zmiany albo zniesienia stosunku prawnego (osiągnięcia tym samym skutku prawnego) jest czynnością faktyczną, przy czym działania faktyczne to zarówno takie, które nie wywołują skutków prawnych, jak i te, które mogą wywołać pośredni skutek prawny w sferze praw i obowiązków jednostek, a w związku z tym ze względu na ochronę obywatela powinno tu funkcjonować swoiste domniemanie, że są one działaniami prawnymi ${ }^{11}$.

I w tym stanowisku można dostrzec element woli traktowany jako istotne kryterium odróżnienia aktów od czynności. Bezpośredni zamiar wywołania skutków prawnych charakteryzuje proces konstruowania aktu (i to aktu w różnych jego możliwych postaciach, w tym aktu indywidualnego i aktu generalnego). Istotny jest tu etap twórczej analizy, której rezultatem jest zamierzony skutek prawny.

\footnotetext{
10 Ibidem, s. 323.

11 J. Zimmermann, Prawo..., s. 47-48.
} 
Skutek prawny w przypadku aktu jest zdeterminowany wynikiem splotu prawa i faktu i stanowi rezultat tego splotu. W przypadku czynności skutek prawny (jeżeli zaistnieje) może być następstwem samego faktu. Idzie oczywiście o rozłożenie akcentów. Wszak sam zamiar wywołania skutków prawnych jest niewystarczający dla ich zaistnienia, konieczny jest jeszcze fakt wydania aktu i jego wprowadzenia do obrotu prawnego (doręczenia, ogłoszenia). Z drugiej strony fakt dokonania czynności nie oznacza, że jest ona przedsiębrana bez woli osiągnięcia określonego skutku prawnego, ale może tak być. Skutek prawny może tu być jedynie w pewien sposób związany z samym faktem dokonania czynności i to niezależnie od tego, czy i jaki proces analityczny poprzedzał jej dokonanie. Myślę, że w tym kontekście należy odczytywać stanowisko J. Borkowskiego wyrażone na tle regulacji art. 16 ust. 1 pkt 4 ustawy o NSA z 1995 roku ${ }^{12}$, według którego

Przepis stanowi o „aktach” i o „czynnościach”, ale nie wydaje się, żeby w samej rzeczy odnosił się do dwóch różnych prawnych form działania. Te dwa określenia występujące w przepisie muszą odnosić się do indywidualnych czynności materialno-technicznych, które powodują powstanie skutku prawnego przez fakty. [...] Czynności materialno-techniczne stanowią formę działania używaną wtedy, gdy należy stosować prawo materialne bez wchodzenia w spór co do jego treści lub ze względu na to, że nie trzeba dokonywać jego ustalenia. $Z$ tego też względu do zastosowania tej prawnej formy działania administracji wystarcza w pewnych przypadkach całkiem uproszczona procedura administracyjna, a częściej - wystarcza przy ich stosowaniu zachowanie tylko nielicznych formalności ułatwiających zastosowanie prawa materialnego $\mathrm{w}$ danym stanie prawnym i faktycznym. [...] Czynność materialno-techniczna stanowi prosty przypadek stosowania prawa bez odwoływania się do względów celowości, a wobec tego zarówno sąd administracyjny, jak i organ administracji publicznej — przynajmniej teoretycznie — powinny określić uprawnienie lub obowiązek na podstawie obowiązującego prawa ${ }^{13}$.

Do najważniejszych działań faktycznych J. Zimmermann zalicza działania materialno-techniczne charakteryzujące się tym, że wywołują one skutki prawne w sposób pośredni drogą faktów lub zdarzeń ${ }^{14}$, przy czym wskazuje na znaną nauce specjalną kategorię działań bezpośrednio zobowiązujących.

Przykład działań bezpośrednio zobowiązujących pozwala dostrzec kolejne cechy zewnętrznych czynności materialno-technicznych.

\section{IV}

Zgodnie z charakterystyką przedstawioną przez J. Zimmermanna działania bezpośrednio zobowiązujące rozumiane są jako

12 Ustawa z dnia 11 maja 1995 r. o Naczelnym Sądzie Administracyjnym (Dz.U. z 1995 r. $\mathrm{Nr} 74$, poz. 368 ze zm.).

13 J. Borkowski, Podmiot uprawniony do wniesienia skargi do sądu administracyjnego w świetle ustawy o Naczelnym Sądzie Administracyjnym, „Samorząd Terytorialny” 1997, nr 5, s. 7-8.

14 J. Zimmermann, Prawo..., s. 461.

Prawo 327, 2019

(C) for this edition by CNS 
pewna całość, na którą składają się zarówno rozstrzygnięcie o obowiązkach [...], jak i nadanie temu rozstrzygnięciu technicznego wymiaru [...]. Z punktu widzenia adresata jest to jedna czynność i można rozważać zakwestionowanie lub zaskarżenie jej jako całości. Ta właśnie czynność staje się również elementem hipotezy i jednocześnie dyspozycji [...] normy zawartej w samej ustawie, zobowiązującej ogólnie do podporządkowania się takim działaniom, jeśli zostaną one podjęte. [...] Indywidualizacja obowiązków wynika ze zdarzeń faktycznych lub z sytuacji faktycznej, w jakiej znalazł się ich adresat. Po jej powstaniu zaczyna wywierać skutek ogólna norma ustawowa zobowiązująca do danego zachowania się, skonkretyzowana nie przez akt administracyjny, ale przez czynność bezpośrednio zobowiązującą. [...] Stwierdzenie, że zaistniała dana sytuacja faktyczna i że ktoś stał się w ten sposób adresatem normy, nie jest odrębnym aktem administracyjnym ani nawet nie stanowi kolejnego ogniwa konkretyzacji tej normy. Co więcej, takie stwierdzenie jest najczęściej zbędne, a czasem formułowane w sposób dorozumiany. Sam mechanizm wywoływania skutków przez działania bezpośrednio zobowiązujące organów administracyjnych jest więc tożsamy z tym, który możemy zaobserwować w odniesieniu do obowiązków wynikających wprost z ustawy (tzw. zakazy i nakazy ustawowe) ${ }^{15}$.

Działania bezpośrednio-zobowiązujące mogą mieć charakter konkretny i abstrakcyjny (ustawienie znaku drogowego, znaku zakazu wstępu do lasu itp.), jak i indywidualny i konkretny (gest policjanta wskazującego kierunek jazdy na skrzyżowaniu).

Działania bezpośrednio-zobowiązujące można zatem w powyższym ich ujęciu rozpisać na dwa nierozerwalnie ze sobą powiązane przejawy aktywności organu. Pierwszy, wewnętrzny i niedostrzegalny przez jego adresata, to etap formułowania w pewnym procesie myślowym normy generalnej (stanowiącej później treść np. znaku drogowego, znaku zakazu wstępu do lasu itp.) lub indywidualnej (np. stanowiącej później treść gestu policjanta wskazującego kierunek jazdy na skrzyżowaniu). J. Zimmermann mówi tu o ,pprocesie myślowym doprowadzającym do danego rozstrzygnięcia"16. Drugi to czynność materialno-techniczna rozumiana jako uzewnętrzniona aktywność wyrażająca treść wcześniej sformułowanej normy (ustawienie znaku drogowego, wykonanie gestu ręką przez policjanta). Spostrzeżenie powyższe ma walor bardziej uniwersalny i potwierdza wyżej sygnalizowaną podstawową różnicę pomiędzy aktem a czynnością. Akt jest rezultatem procesu myślowego prowadzącym do wykreowania nowej normy (norma ta może mieć różny charakter) i w tym znaczeniu stanowi ,zamkniętą całość”. Czynność natomiast stanowi swojego rodzaju dopełnienie normy, element konieczny bądź dla zaistnienia normy w przestrzeni prawnej, bądź dla wywołania przez nią skutków prawnych, bądź też dla osiągnięcia obydwu tych rezultatów. Akt tworzy normę, a czynność dotyczy istniejącej już normy.

Z perspektywy zewnętrznego obserwatora różnica ta nie zawsze jest dostrzegalna. Częściej nawet z tej perspektywy określona czynność bywa traktowana jako zachowanie normatywne, bo to właśnie ,przez nią” w ostatecznym rozrachunku

15 J. Zimmermann, Prawo..., s. 443-444.

16 Ibidem, s. 442. 
np. należy skręcić w lewo, nie można wejść do lasu, urzeczywistnia się zmiana charakteru wykonywanej służby publicznej.

Myślę, że w tym właśnie kontekście J. Zimmermann, odnosząc się do działań indywidualnych i konkretnych, stwierdza, że

w tym wypadku działanie funkcjonariusza zastępuje typowy akt administracyjny (decyzję administracyjną), gdyż konkretyzuje do końca adresata normy i jej przedmiot oraz jest jednorazowo (niepowtarzalnie) wykonywanym aktem stosowania prawa. Różnica między takim działaniem a aktem administracyjnym polega na tym, że działanie to nie ma ustalonej formy (nie może być nazwane aktem, ale jedynie czynnością) ani nie jest podejmowane na podstawie sformalizowanej procedury $^{17}$.

Powyższe ujęcie zagadnienia wydobywa zatem jego aspekty formalne, których jednak nie sposób odrywać od uwarunkowań materialnych. Oderwane od powyższego kontekstu stwierdzenie, że działanie, które nie ma ustalonej formy nie może być nazwane aktem, ale jedynie czynnością, mogłoby rodzić wątpliwości. Przyjmując bowiem, że formy działania administracji publicznej wynikają z norm prawnych te formy określających, można by na tle powyższego twierdzenia wyrażać wysoce kontrowersyjny pogląd, że brak wskazania przez ustawodawcę na formę aktu administracyjnego (decyzji) dla określonego działania wyklucza z tego właśnie powodu możliwość kwalifikowania tego działania jako aktu administracyjnego. Stanowiska takiego nie sposób byłoby zaakceptować, mając dodatkowo na uwadze, że konstrukcja tzw. domniemania formy aktu administracyjnego została już wiele lat temu słusznie przyjęta w doktrynie prawa administracyjnego ${ }^{18}$ i zaakceptowana w orzecznictwie sądowoadministracyjnym ${ }^{19}$. Milczenie ustawodawcy w kwestii formy określonego działania nie może wykluczać zakwalifikowania go do kategorii aktu administracyjnego, jeżeli działanie to spełnia wszystkie materialne cechy aktu administracyjnego.

Wydaje się, że określone działanie bezpośrednio zobowiązujące — i to zarówno o charakterze konkretnym i abstrakcyjnym, jak i o charakterze indywidualnym i konkretnym — nie może być kwalifikowane jako akt nie dlatego, że nie ma ustalonej formy aktu administracyjnego, lecz dlatego, że nie ma cech takiego aktu rozumianego — w przypadku aktu indywidualnego — dodatkowo jako rezultat „materialnej” jurysdykcji administracyjnej. Rozmaite klasyfikacje aktów

17 Ibidem, s. 444.

18 B. Adamiak, Zagadnienie domniemania formy decyzji administracyjnej, [w:] Podmioty administracji publicznej i prawne formy ich działania. Studia i materiały z Konferencji Naukowej poświęconej Jubileuszowi 80-tych urodzin Profesora Eugeniusza Ochendowskiego, Toruń 2005, s. 18; J. Jendrośka, B. Adamiak, glosa do wyroku NSA z dnia 27 kwietnia 1981 r., SA 767/81, OSP 1983, nr 5, poz. 109; S. Zawadzki, J. Świątkiewicz, Z doświadczeń NSA, „Państwo i Prawo” 1981, nr 6, s. 8; J. Łętowski, Prawo administracyjne. Zagadnienia podstawowe, Warszawa 1990, s. 253; J. Zimmermann, Polska jurysdykcja administracyjna, Warszawa 1996, s. 138-140.

19 Zob. np. wyrok NSA we Wrocławiu z dnia 31 sierpnia 1984 r., SA/Wr 430/84, OSP z 1986/9-10, poz. 176; wyrok NSA z dnia 5 grudnia 2017 r., I OSK 934/17; wyrok NSA z dnia 27 października 2017 r., I OSK 3377/15; wyrok NSA z dnia 25 października 2016 r., II GSK 3246/16. 
administracyjnych ukazujące ich różne cechy charakterystyczne nie podważają tezy o nieodzownym elemencie każdego aktu administracyjnego, jakim jest jego rozstrzygnięcie. W stosunku do aktu indywidualnego doktryna jest zgodna co do tego, że jednym z czterech konstytutywnych elementów takiego aktu jest właśnie „rozstrzygnięcie”. Mając przy tym na uwadze, że pozostałe elementy konstytutywne takie jak: „oznaczenie organu”, „,oznaczenie strony lub stron” oraz „podpis pracownika organu, upoważnionego do wydania aktu" to w istocie elementy formalne dokumentu, ,rozstrzygnięcie” można traktować jako materialny wyróżnik aktu administracyjnego.

Działanie bezpośrednio-zobowiązujące nie bez powodów nie jest zaliczane do aktów administracyjnych, a zatem — z perspektywy materialnoprawnej — nie sposób odnosić do niego materialnego wyróżnika aktu administracyjnego, tj. rozstrzygnięcia rozumianego jako orzeczenie o czyichś uprawnieniach lub obowiązkach, przesądzenie o konsekwencjach normy prawnej w danej sytuacji faktycznej ${ }^{20}$.

W przypadku działania bezpośrednio-zobowiązującego o charakterze indywidualnym i konkretnym należy mieć na uwadze, że wprawdzie działanie takie podejmowane jest na podstawie normy materialnoprawnej, konkretyzuje do końca adresata normy i jej przedmiot oraz jest jednorazowo (niepowtarzalnie) wykonywanym aktem stosowania prawa, nie jest jednak ukierunkowane na wykreowanie rozstrzygnięcia w jego wyżej przyjętym rozumieniu, a zatem nie może być wynikiem „materialnych” działań charakteryzujących mechanizm przygotowania aktu administracyjnego, tj. działań zmierzających właśnie do wykreowania rozstrzygnięcia. Działanie to stanowi ,jedynie" reakcję prawną czasem reakcję natychmiastową — kompetentnego podmiotu na pojawiający się w ściśle określonym miejscu i czasie splot okoliczności faktycznych adekwatną do tych okoliczności, ukierunkowaną przede wszystkim na osiągnięcie celu w zakresie stanu faktycznego ${ }^{21}$ (a nie na ukształtowanie w pierwszej kolejności czyichś praw i obowiązków) i podejmowaną bez konieczności analizy sytuacji prawnych (praw podmiotowych, interesów prawnych, interesów faktycznych) podmiotów, do których jest kierowane. W działaniu takim element charakterystyczny dla aktu prawnego (w ogólnym rozumieniu) zdominowany jest przez element faktyczny — czynność. Oddziaływanie takiej czynności (będącej częścią składową działania bezpośrednio-zobowiązującego), jak również czynności o charakterze konkretnym i abstrakcyjnym, jest możliwe wyłącznie w sytuacji znalezienia się jej adresata bezpośrednio w ,polu jej oddziaływania” i z tego względu jest ona natychmiast wykonalna. Nie wywołuje skutków dłużej niż przez czas trwania okoliczności faktycznych, do których się ona odnosi. Okoliczność, że „akt myślowy" i czynność urzeczywistniająca go w przestrzeni prawnej nie są podejmowane

20 J. Zimmermann, Polska jurysdykcja..., s. 129.

21 Por. K.M. Ziemski, Indywidualny akt administracyjny jako forma prawna działania administracji, Poznań 2005, s. 476. 
w sformalizowanej procedurze jest konsekwencją takiej właśnie natury działania bezpośrednio-zobowiązującego.

Cechą charakterystyczną takich działań nie jest — właściwy aktom administracyjnym - objaw woli organu administracyjnego skierowany bezpośrednio na utworzenie, zmianę lub zniesienie stosunków prawnych, lecz bezpośrednia reakcja prawna na określone fakty mogąca dopiero w dalszej kolejności wpływać na kształtowanie stosunków prawnych. Skutek prawny jest cechą wtórną czynności faktycznych i stanowi, jak wskazuje Z. Kmieciak, pewnego rodzaju „odbicie” realnego skutku, który nastąpił w sferze pewnych stanów faktycznych ${ }^{22}$. Czynność materialno-techniczna, stanowiąc fakt prawotwórczy, nie rozstrzyga o konsekwencjach prawnych, w przeciwieństwie do aktu administracyjnego, którego istotą jest rozstrzyganie o konsekwencjach prawnych. O ile akt administracyjny wywołuje skutki prawne będące konsekwencją zawartego w nim rozstrzygnięcia, o tyle w przypadku czynności materialno-technicznych wywołane przez nie skutki prawne są bezpośrednim następstwem faktów a nie rozstrzygnięć, których w tych czynnościach brak.

\section{V}

W polskiej doktrynie na kryterium „rozstrzygania” rozumianego jako świadome i celowe dokonywanie przesądzania o konsekwencjach prawnych dla stwierdzonego stanu faktycznego wskazuje K.M. Ziemski ${ }^{23}$ jako na kryterium odróżniania aktów administracyjnych od czynności materialno-technicznych. Autor ten podkreśla, że w przypadku aktu administracyjnego rozstrzyganie i jego rezultat (a więc rozstrzygnięcie) nie dotyczy przesądzania o okolicznościach faktycznych, lecz o konsekwencjach prawnych stwierdzonych okoliczności faktycznych ${ }^{24}$. Przesądzanie o okolicznościach faktycznych może być rozumiane najwyżej jako rozstrzyganie $\mathrm{w}$ rozumieniu potocznym bądź $\mathrm{w}$ sensie psychologicznym ${ }^{25}$, a nie w znaczeniu, jakie odnosi się do aktu administracyjnego ${ }^{26}$.

Powyższa charakterystyka koresponduje też w znacznym stopniu ze stanowiskiem J. Starościaka, który twierdził, że czynności materialno-techniczne są takim przejawami działań administracji, które kształtują nowe stosunki prawne nie przez bezpośrednie tworzenie nowej normy obowiązującego porządku prawnego, lecz przede wszystkim przez fakty ${ }^{27}$. Takie ujęcie zagadnienia, w którym skutek

22 Z. Kmieciak, Czynności faktyczne administracji państwowej, „Studia Prawno-Ekonomiczne" 1987 , t. 39, s. 78.

23 Por. K.M. Ziemski, Indywidualny akt..., s. 477-479, 490-491.

${ }^{24}$ Ibidem, s. 490.

25 M. Wierzbowski, A. Wiktorowska, op. cit., s. 213.

26 Por. K.M. Ziemski, Indywidualny akt..., s. 479.

27 J. Starościak, op. cit., s. 299. 
prawny działania dystansuje się od normy prawnej a łączy ze zdarzeniem faktycznym, uwypukla inną jeszcze cechę czynności materialno-technicznych. Należy bowiem przyjąć, że w ujęciu chronologicznym podejmowanie kolejnej czynności materialno-technicznej nie jest ,związane” wcześniejszą tego rodzaju czynnością podjętą w tej samej kwestii, jeżeli zmieniły się okoliczności faktyczne. Kolejna czynność automatycznie niweczy skutek poprzedniej bez potrzeby „eliminowania” wcześniejszej czynności z przestrzeni prawnej. W przypadku normy — zarówno generalno-abstrakcyjnej, jak i indywidualno-konkretenej — zmiana okoliczności faktycznej automatycznie nie niweczy skutków obowiązywania normy prawnej.

Jeżeli więc działanie organu administracji publicznej nie jest ukierunkowane w pierwszej kolejności na osiągnięcie celu w postaci orzeczenia o czyichś uprawnieniach lub obowiązkach w konsekwencji przesądzenia o konsekwencjach normy prawnej w danej sytuacji faktycznej, lecz przede wszystkim i w pierwszej kolejności na osiągnięcie celu w zakresie stanu faktycznego, który następnie może determinować ukształtowanie czyjejś sytuacji prawnej — w tym również determinować orzeczenie o czyichś uprawnieniach lub obowiązkach, jak i treść tego orzeczenia - to stanowi zewnętrzną czynność materialno-techniczną.

Charakterystyka ta odpowiada poglądom doktryny, zgodnie z którymi czynności prawne mogą kształtować stosunki prawne poprzez normy postępowania, a czynności faktyczne czynią to poprzez fakty, a nie normy postępowania ${ }^{28}$

Cechą charakterystyczną czynności materialno-technicznych jest wywoływanie określonych skutków prawnych drogą faktów. Czynności materialno-techniczne kształtują nowe stosunki prawne przez fakty, a nie przez tworzenie norm porządku prawnego. [...] Są działaniami faktycznymi, pojawiają się jako rzeczywiste zdarzenie, a nie normy postępowania i nie powodują też powstania żadnej normy postępowania ${ }^{29}$.

\section{VI}

Charakterystykę działań faktycznych administracji warto uzupełnić o stanowisko A. Błasia, który podkreśla, że działania te są podejmowane w występujących w administracji procesach stosowania prawa i chociaż są podejmowane na podstawie i w granicach prawa, to albo w ogóle nie są prawem określone albo są określone prawem ,w sposób niewyczerpujący, omijający takie elementy owych działań, jak warunki ich podejmowania, treść, forma i tryb ich podejmowania,

28 M. Wierzbowski, A. Wiktorowska, op. cit., s. 213. Zob. też K.M. Ziemski, Formy prawne realizacji materialnego prawa administracyjnego, [w:] Rola materialnego prawa administracyjnego a ochrona praw jednostki, red. Z. Leoński Poznań 1998, s. 67.

29 M. Wierzbowski, A. Wiktorowska, op. cit., s. 215. 
zasady kontroli ich prawidłowości”"30. Wśród rozmaitych form działań faktycznych A. Błaś wyróżnia działania podejmowane w ramach jurysdykcyjnego postępowania administracyjnego, działania faktyczne zmierzające do nawiązania współpracy z obywatelami, działania informacyjne administracji oraz właśnie działania faktyczne o charakterze materialno-technicznym ${ }^{31}$.

Wśród działań o charakterze zewnętrznym wyodrębnia zwłaszcza część działań informacyjnych związanych z ochroną praw podmiotowych obywatela i w tym zakresie wskazuje na regulacje Ustawy z dnia 6 września 2001 roku o dostępie do informacji publicznej ${ }^{32}$, a także część działań o charakterze materialno-technicznym, podkreślając, że

czynności te wywołują skutki prawne poprzez fakty dokonywane przez organy administracyjne lub upoważnionych przedstawicieli tych organów. Technika dokonywania takich faktów nie musi być i najczęściej nie jest regulowana przepisami prawa, przepisy te muszą jednakże wyraźnie upoważniać organy administracyjne do dokonywania takich czynności. Gdy dokonywanie takich czynności wiąże się z kontrolą wykonywania obowiązków przez obywatela lub czynności te związane są z przymusowym wykonaniem tych obowiązków, upoważnienia do dokonania takich czynności muszą być zawarte w aktach prawnych rangi ustawowej [...]. Działania faktyczne nie są skierowane na wywołanie bezpośrednich skutków prawnych w sferze praw i obowiązków jednostki. Jednakże w zakresie, w jakim działania faktyczne wywołują skutki prawne pośrednio w sferze praw i obowiązków jednostki, stanowiły przedmiot kontroli dotychczasowego Naczelnego Sądu Administracyjnego i będą stanowić przedmiot kontroli aktualnego sądownictwa administracyjnego ${ }^{33}$.

W poglądach A. Błasia warto zatem zauważyć ścisłe wiązanie zewnętrznych czynności faktycznych, w tym materialno-technicznych, organów administracji publicznej z kategorią kompetencji administracyjnej i potrzebą kontroli sądowoadministracyjnej sposobu czynienia przez organy użytku z tej kompetencji. Stanowisko to, będące kontynuacją wcześniejszych poglądów nauki, należy w pełni zaakceptować, mając ciągle na uwadze związek zewnętrznych czynności materialno-technicznych administracji ze sferą praw i obowiązków adresatów tych czynności.

\section{VII}

Dostrzeganemu w nauce kryterium publicznych praw podmiotowych jednostek i ochrony tych praw warto poświęcić uwagę jako kolejnemu istotnemu kryterium pozwalającemu uchwycić granicę pomiędzy zewnętrznymi czynnościa-

30 A. Błaś, Formy działań faktycznych, [w:] Prawo administracyjne, red. J. Boć, Wrocław 2004, s. 426-427.

31 Ibidem, s. 350.

32 Ustawa z dnia 6 września 2001 r. o dostępie do informacji publicznej (tekst jedn. Dz.U. z 2018 r. poz. 1330).

33 A. Błaś, op. cit., s. 355-356. 
mi materialno-technicznymi a aktami administracyjnymi. Często bowiem teoretyczne konstrukcje nauki prawa administracyjnego traktowane są jako niemające praktycznego znaczenia rezultaty rozważań naukowych na płaszczyznach wyłącznie abstrakcyjnych. Tymczasem jednym z istotnych atutów tych konstrukcji jest właśnie to, że pozwalają wyjaśnić kwestie nie dość jasne, służąc prawidłowemu stosowaniu prawa w konkretnych sprawach. Kwestie te rozważałem wiele lat temu przy okazji refleksji na temat materialnego rozumienia decyzji administracyjnych $^{34}$ i jest obecnie okazja, aby przyjrzeć się im z perspektywy charakterystyki zewnętrznych czynności materialno-technicznych.

Istotne jest $\mathrm{w}$ tym zakresie nawiązanie do podziału publicznych praw podmiotowych na prawa wynikające bezpośrednio z woli prawodawcy i prawa powstające w wyniku władczej i samodzielnej działalności organów administracji publicznej w ramach przyznanych im kompetencji ${ }^{35}$. Ważne jest tu zwrócenie uwagi na wspomniane kryterium bezpośredniości, które oznacza, że o ile w przypadku pierwszej grupy tych praw związek pomiędzy publicznym prawem podmiotowym a normą prawną stanowiącą jego źródło jest tak ścisły, że prawo to istnieje w obrocie prawnym bez konieczności jego ,uruchomienia” przez organ państwa w określonych i adekwatnych ku temu formach działania (innymi słowy: prawo to funkcjonuje „bez pośrednictwa” innego podmiotu), o tyle w przypadku drugiej grupy tych praw związek pomiędzy normą prawną jako niezbędnym źródłem publicznego prawa podmiotowego a budowanym na niej prawem jest tego rodzaju, że elementem niezbędnym do wykreowania na podstawie tej normy publicznego prawa podmiotowego bądź do skorzystania z prawa wynikającego $\mathrm{z}$ tej normy jest „pośrednictwo” innego podmiotu, tj. kompetentnego organu państwa. Pośrednictwo to polega na „pracy nad normą” (jej „obrabianiu”), a zatem zawiera element „twórczy” („,sprawczy”), stąd działanie organu w przypadku drugiej grupy praw musi przybierać formę takiego oświadczenia woli, które ukierunkowane jest na twórcze kształtowanie zakresu sfery prawnej adresata takiego działania, tj. formę aktu administracyjnego odpowiednio konstytutywnego lub deklaratoryjnego. W sytuacji, gdy nie jest konieczne konkretyzowanie i indywidualizowanie normy prawnej, bo jest już ona zdolna sama wywoływać skutki w sferze prawnej jej adresata, działania kompetentnych podmiotów państwa podejmowane w odniesieniu do tego rodzaju norm i budowanych na nich praw w stopniu jedynie oddziałującym i to wyłącznie na realizowanie tych praw nie mają charakteru „twórczego" wobec zakresu sfery prawnej adresata takiego działania, przez co nie uzyskują charakteru aktów administracyjnych.

Organ stojący przed zadaniem doboru adekwatnej formy działania do tego właśnie działania — w obliczu braku norm określających formę działania — powi-

34 Zob. W. Jakimowicz, Problem definiowania pojęcia decyzji administracyjnej, „Przegląd Sądowy" 2000, nr 10, s. 42-49.

35 Zob. W. Jakimowicz, Publiczne prawa podmiotowe, Kraków 2002, s. 185-191. 
nien zatem ustalić, czy istota tego działania koncentruje się na wykreowaniu publicznego prawa podmiotowego adresata jego działań, umożliwieniu skorzystania $z$ tego prawa przez tego adresata czy też jedynie na oddziaływaniu na realizowanie istniejącego już prawa przez podmiot tego prawa. Chodzi przy tym o istotę działania, a nie o dodatkowe aspekty prawne tego działania (możliwe są sytuacje, gdy wśród różnych skutków wydania określonego aktu administracyjnego znajdą się i takie, które nie pozostaną obojętne dla realizowania czyjegoś prawa podmiotowego). Należy wykluczyć formę aktu administracyjnego wtedy, gdy istota konkretnie ukierunkowanego działania organu koncentruje się wyłącznie na wpływaniu tego działania na realizowanie istniejącego już w obrocie prawnym publicznego prawa podmiotowego przez podmiot tego prawa bez kształtowania zakresu sfery prawnej adresata takiego działania. W takiej sytuacji aktywność organu przejawia się w takich oświadczeniach woli, które nie są ukierunkowane na twórcze kształtowanie zakresu sfery prawnej adresata jego działania bądź w oświadczeniach wiedzy (przekazanie wiedzy, tj. poinformowanie nie wyznacza granic sfery prawnej podmiotu informowanego). Tego rodzaju oświadczenia skierowane na zewnątrz administracji w formie różnego typu pism, propozycji, deklaracji, informacji itp. tworzą z perspektywy ich adresata kategorię zewnętrznych czynności materialno-technicznych ${ }^{36}$.

\section{VIII}

Adresaci zewnętrznych czynności materialno-technicznych korzystają z ochrony sądowoadministracyjnej w polskim porządku prawnym od dnia 1 października 1995 roku, tj. od dnia wejścia w życie Ustawy z dnia 11 maja 1995 roku o Naczelnym Sądzie Administracyjnym. Według art. 16 ust. 4 tej ustawy do sądu administracyjnego zaskarżalne były inne niż decyzje i postanowienia ,akty lub czynności z zakresu administracji publicznej dotyczące przyznania, stwierdzenia albo uznania uprawnienia lub obowiązku wynikających z przepisów prawa", a sąd, uwzględniając skargę na czynność, orzekał o istnieniu obowiązku lub uprawnienia i stwierdzał bezskuteczność czynności (art. 23 ustawy). Szeroka formuła ustawowa pozwalała objąć ochroną obszerny katalog czynności materialno-technicznych i jako taka zasługiwała na aprobatę. Trafne było również przyjęcie przez ustawodawcę elementu skutku jako elementu charakteryzującego czynności materialno-techniczne i wyposażenie sądu administracyjnego w kompetencje do stwierdzania bezskuteczności czynności czyli pozbawiania z mocą wsteczną waloru prawnego

36 Oświadczenia wiedzy, takie jak indywidualne interpretacje prawa podatkowego zalicza się w orzecznictwie do zewnętrznych czynności materialno-technicznych. Zob. np. wyrok WSA w Poznaniu z dnia 25 listopada 2010 r., I SA/Po 632/10; wyrok WSA w Poznaniu z dnia 27 stycznia 2011 r., I SA/Po 906/10. 
tych skutków. Ochronę ustawową wynikającą z powyższego unormowania należy zatem ocenić jako adekwatną do charakteru zewnętrznych czynności materialno-technicznych. Rozstrzygające praktyczne znaczenie miała jednak w tym zakresie wykładnia art. 16 ust. 4 ustawy o NSA z 1995 roku dokonywana w orzecznictwie Naczelnego Sądu Administracyjnego, która niestety — jak się następnie okazało - konsekwentnie zmierzała do zawężającego rozumienia powyższej regulacji.

Od samego początku na tle powyższego unormowania przy braku wątpliwości, że przepis ten dotyczył czynności materialno-technicznych organów administracji publicznej ${ }^{37}$, zarysowały się odmienne stanowiska w kwestii jego wykładni. W uzasadnieniu uchwały z dnia 7 grudnia 1998 roku, FPS 18/98 Naczelny Sąd Administracyjny, wskazując, że przepis art. 16 ust. 1 pkt 4 ustawy o NSA nie został sformułowany precyzyjnie, a jego wykładnia może prowadzić do rozbieżnych wniosków, podkreślał, że

konstruując przepisy art. 16 ustawy o NSA, ustawodawca kierował się potrzebą zagwarantowania realnej ochrony zainteresowanym nią podmiotom. Powstające zatem wątpliwości co do dopuszczalności zaskarżenia do sądu administracyjnego określonego aktu lub czynności na podstawie art. 16 ust. 1 pkt 4 ustawy o NSA nie powinny być rozstrzygane na niekorzyść wnoszącego skargę. Tylko taki sposób wykładni analizowanego przepisu pozostaje w zgodzie z zawartą w art. 45 ust. 1 konstytucji RP zasadą prawa do sądu oraz kreującymi to prawo postanowieniami ratyfikowanych przez Polskę aktów prawa międzynarodowego: art. 14 Międzynarodowego paktu praw obywatelskich i politycznych (Dz.U. z 1977 r. Nr 38, poz. 167 i 168) oraz art. 6 Konwencji o ochronie praw człowieka i podstawowych wolności (Dz.U. z 1992 r. Nr 85, poz. 427 i Dz.U. z 1993 r. Nr 61, poz. 284). Inaczej mówiąc, wobec niedostatecznej precyzji, a nawet niejasności przepisu art. 16 ust. 1 pkt 4 ustawy o NSA, trzeba - w wypadkach budzących wątpliwości interpretacyjne — przyjąć takie jego znaczenie, które jest najpełniej zharmonizowane z postanowieniami konstytucyjnymi i standardami ukształtowanymi przez akty prawa międzynarodowego. To założenie podporządkowane jest z kolei ogólniejszym dyrektywom ochrony praw jednostki, wypływającym z wyrażonej w art. 2 konstytucji RP zasady demokratycznego państwa prawa.

W konsekwencji NSA przyjął, że wydanie wyniku kontroli skarbowej jest czynnością z zakresu administracji publicznej podlegającą kontroli sądu administracyjnego.

Stanowisko powyższe korespondowało z poglądami prezentowanymi w doktrynie. J. Zimmermann wskazywał, że

Ustawa z dnia 11 maja 1995 r. o Naczelnym Sądzie Administracyjnym z założenia miała się przyczynić do rozszerzenia zakresu działania tego Sądu w taki sposób, aby obejmował on swoją właściwością kontrolę możliwie wszystkich działań zewnętrznych administracji publicznej. [...] Unormowanie [art. 16 ust. 1 pkt 4 ustawy o NSA - przyp. W.J.] jest pożyteczne, gdyż rozszerza znacznie przysługujące obywatelowi prawo do sądu, jest ono jednak stosowane w praktyce rzadko lub bardzo rzadko $[\ldots]^{38}$.

37 Zob. T. Woś, Postępowanie sądowoadministracyjne, Warszawa 1996, s. 61; B. Adamiak, J. Borkowski, Polskie postepowanie administracyjne i sadowoadministracyjne, Warszawa 1996, s. 280.

38 Por. glosa J. Zimmermanna do postanowienia NSA z dnia 24 marca 1998 r., II SA 1155/97, OSP 1999, nr 9, poz. 164.

Prawo 327, 2019

(C) for this edition by CNS 
Już jednak w uzasadnieniu uchwały z dnia 26 kwietnia 1999 roku, FPS 5/99 Naczelny Sąd Administracyjny wskazywał, że

choć przepis art. 16 ust. 1 pkt 4 ustawy o NSA uchodzi za niejasny [...], co stwarza dość szeroki stopień swobody jego wykładni, w przekonaniu niniejszego składu sędziowskiego są granice korzystania z wyznaczonego nim luzu interpretacyjnego. Użycie przez ten przepis słów: „stwierdzenia albo uznania uprawnienia lub obowiązku wynikających z przepisów prawa" oznacza objęcie kontrolą Sądu takich aktów lub czynności, które wywołują konsekwencje dotyczące sfery praw i obowiązków danego podmiotu, bezpośrednie i poddające się prawnej kategoryzacji. Waloru tego nie mają zawarte w wystąpieniu pokontrolnym wnioski, zmierzające do usunięcia dostrzeżonych nieprawidłowości i usprawnienia badanej działalności [...]. Skierowanie do właściwej jednostki wystąpienia pokontrolnego, podobnie jak inne działania organów kontroli państwowej, nie wpływa samo przez się na sytuację kontrolowanego [...].

W późniejszym orzecznictwie sądowym dostrzegalna była tendencja do zawężającej wykładni art. 16 ust. 4 ustawy o NSA z 1995 roku. Nawet stanowisko przyjęte w uchwale z dnia 7 grudnia 1998 roku, FPS 18/98 zaczęto w orzecznictwie „wykładać” zawężająco, przyjmując, że

Wynik kontroli może być zaskarżony do Naczelnego Sądu Administracyjnego tylko wówczas, gdy odpowiada pojęciu ,aktu lub czynności z zakresu administracji publicznej dotyczącego przyznania, stwierdzenia albo uznania uprawnienia lub obowiązków wynikających z przepisów prawa" w rozumieniu art. 16 ust. 1 pkt 4 ustawy z dnia 11 maja 1995 r. o Naczelnym Sądzie Administracyjnym ${ }^{39}$.

Również w piśmiennictwie przyjmowano, że ,akty i czynności poddane kontroli na podstawie tego przepisu dotyczą sytuacji skonkretyzowanych, gdzie akt (czynność) jest źródłem uprawnienia albo obowiązku ${ }^{40}$.

Tendencja powyższa dostrzegalna jest również na tle późniejszych unormowań ustawowych. E. Łętowska odnosząc się do treści art. 16 ust. 4 ustawy o NSA z 1995 roku wskazywała, że

w punktach 1-3 art. 16 ust. 1 ustawy o NSA z 1995 r. wymienia się możliwość kontroli decyzji oraz postanowień, na które służy zażalenie, wydanych w postępowaniu administracyjnym lub egzekucyjnym i zabezpieczającym. Natomiast pkt 4 mówi o ,innych niż wymienione [...] aktach lub czynnościach z zakresu administracji publicznej dotyczących przyznania, stwierdzenia albo uznania uprawnienia lub obowiązków wynikających z przepisów prawa”. Formuła ta uległa uproszczeniu i liberalizacji od 1 stycznia 2004 r., ponieważ art. 3 § 2 pkt 4 ustawy z 30 sierpnia 2002 r. mówi o kontroli aktów i czynności „,z zakresu administracji publicznej dotyczących uprawnień lub obowiązków wynikających z przepisów prawa”. Pominięto więc wzmiankę o „,przyznaniu, stwierdzeniu albo uznaniu” uprawnień lub obowiązków przez „akty i czynności” objęte kontrolą. Przepis art. 16 ust. 1 pkt 4 ustawy o NSA jest przepisem subsydiarnym wobec poprzedzających go przepisów pkt 1-3. Jest to o tyle ważne, że wskazuje na „wspólny mianownik” zdarzeń kontrolowanych przez NSA, a objętych pkt 1-4 ustępu $1 \mathrm{w}$ art. 16, liczącym wszak w sumie punktów $7^{41}$.

39 Wyrok NSA z dnia 24 listopada 1999 r., III SA 8054/98.

40 M. Masternak-Kubiak, glosa do postanowienia NSA z dnia 16 września 2004 r., OSK 250/04, PS 2005, nr 1, s. 150.

41 E. Łętowska, glosa do wyroku NSA z dnia 29 maja 2003 r., II SAB 419/02, OSP 2004, nr 7-8, poz. 90 .

Prawo 327, 2019

(C) for this edition by CNS 
Rzecz jednak w tym, że w powyższej regulacji nie było mowy o „przyznaniu, stwierdzeniu albo uznaniu” uprawnień lub obowiązków przez „akty i czynności” objęte kontrolą. „Akty i czynności” miały „dotyczyć” przyznania, stwierdzenia albo uznania uprawnienia lub obowiązków wynikających z przepisów prawa, co w żaden sposób nie uprawniało do twierdzenia, że te akty lub czynności są źródłem uprawnień i obowiązków. Źródło to przez ustawodawcę zawsze było wskazywane jako ,przepisy prawa”, co zresztą również było podkreślane w orzecznictwie $^{42}$ i doktrynie ${ }^{43}$ ze wskazaniem, że

przepis art. 16 ust. 1 pkt 4 ustawy o NSA operuje określeniem „dotyczące”. Co prawda jest to słowo niejasne i mylące, jednak jego wykładnia językowa prowadzi do wniosku, że ustawodawca chciał objąć zakresem skargi również takie działania, które same bezpośrednio nie „przyznają”, nie „stwierdzają” ani nie „uznają” uprawnień lub obowiązków, ale które są z takimi działaniami związane jedynie pośrednio ${ }^{44}$.

Trafnie podkreślał M. Bogusz, że w omawianym przepisie chodzi zarówno o uprawnienia lub obowiązki, które wynikają bezpośrednio z przepisów prawa, jak i te, które nie wynikają z tych przepisów bezpośrednio, ale pochodzą od organów administracji publicznej (są ,przyznawane” przez te organy) — „przejaw działania organu stanowi akt lub czynność w rozumieniu art. 16 ust. 1 pkt 4 ustawy o NSA wówczas, gdy do sytuacji prawnej zindywidualizowanego podmiotu prawa, wyznaczonej jego uprawnieniami i obowiązkami, wprowadza prawnie wiążący element »nowości normatywnej«"45.

Obecnie w polskim porządku prawnym do kategorii zewnętrznych czynności materialno-prawnych w ich wyżej przyjętym rozumieniu nawiązuje regulacja art. $3 \S 2$ pkt 4 p.p.s.a., zgodnie z którą kontrola działalności administracji publicznej przez sądy administracyjne obejmuje orzekanie w sprawach skarg na inne niż określone w art. $3 \S 2$ pkt 1-3, ,akty lub czynności z zakresu administracji publicznej dotyczące uprawnień lub obowiązków wynikających z przepisów pra-

42 Wyrok 7 sędziów NSA z dnia 19 maja 2003 r., OSA 1/03, ONSA 2003, nr 4, poz. 114, w którym przyjęto, że ,,pacjent publicznego zakładu opieki zdrowotnej ma uprawnienie do udostępnienia mu dokumentacji medycznej zbiorczej prowadzonej przez zakład, w zakresie dotyczącym jego osoby, wynikające z art. 18 ust. 3 pkt 1 ustawy z dnia 30 sierpnia 1991 r. o zakładach opieki zdrowotnej (Dz.U. Nr 91, poz. 408 ze zm.), a w razie odmowy uznania tego uprawnienia przez zakład może zaskarżyć czynność zakładu do sądu administracyjnego na podstawie art. 16 ust. 1 pkt 4 ustawy z dnia 11 maja 1995 r. o Naczelnym Sądzie Administracyjnym (Dz.U. Nr 74, poz. 368 ze zm.)".

43 B. Adamiak, glosa do wyroku NSA z dnia 19 maja 2003 r., OSA 1/03, OSP 2003, nr 11, poz. 136.

44 J. Zimmermann, glosa do postanowienia NSA z dnia 24 marca 1998 r., II SA 1155/97, OSP 1999, nr 9, poz. 164.

45 M. Bogusz, Pojęcie aktów lub czynności z zakresu administracji publicznej dotyczacych przyznania, stwierdzenia albo uznania uprawnienia lub obowiązk, wynikających z przepisów prawa $w$ rozumieniu art. 16 ust. 1 pkt 4 ustawy o NSA, „Samorząd Terytorialny” 2000, nr 1-2, s. $182-183$.

Prawo 327, 2019

(C) for this edition by CNS 
wa". Istoty tej regulacji — z perspektywy omawianej problematyki — nie zmieniły późniejsze ustawy nowelizujące ten przepis ${ }^{46}$.

Czynności, o jakich mowa w tym przepisie, kwalifikowane są w orzecznictwie właśnie jako zewnętrzne czynności materialnotechniczne charakteryzujące się następującymi cechami ${ }^{47}$ :

1) nie są to czynności stosowania prawa rozumiane jako wyraz woli organu, lecz czynności wykonania (realizacji) prawa, podejmowane wtedy, gdy stosunek prawny nie wymaga konkretyzacji, ponieważ został ukształtowany bezpośrednio przepisami prawa ${ }^{48}$ - odpowiadają zatem nie tyle formule stosowania prawa, ile jego wykonywania, a więc formule wykonawczej, która wyraża się w urzeczywistnianiu (realizacji) dyspozycji normy prawnej kreującej konkretny (a więc już istniejący) stosunek administracyjny i wynikające $\mathrm{z}$ niego uprawnienie lub obowiązek;

2) mają charakter władczy, chociaż nie mają charakteru decyzji lub postanowienia, te bowiem są zaskarżalne na podstawie art. $3 \S 2$ pkt 1-3 p.p.s.a.;

3) mają charakter indywidualny, co wynika z określenia ich przedmiotu, a mianowicie uprawnień lub obowiązków, których dotyczą (przy czym NSA wskazuje tu na związki z publicznymi prawami podmiotowymi jednostki) ${ }^{49}$;

4) mają charakter publicznoprawny, ponieważ tylko w tym zakresie działalność administracji została poddana kontroli sądów administracyjnych;

5) dotyczą uprawnień lub obowiązków wynikających z przepisu prawa, co oznacza, że musi istnieć ścisły i bezpośredni związek między działaniem (zaniechaniem określonego działania) organu administracji a możliwością realizacji

46 Zgodnie z art. 1 pkt 1 Ustawy z dnia 9 kwietnia 2015 r. o zmianie ustawy - Prawo o postępowaniu przed sądami administracyjnymi (Dz.U. z 2015 r. poz. 658) kontroli sądowoadministracyjnej podlegają inne niż decyzje i postanowienia ,akty lub czynności z zakresu administracji publicznej dotyczące uprawnień lub obowiązków wynikających z przepisów prawa, z wyłączeniem aktów lub czynności podjętych w ramach postępowania administracyjnego określonego w ustawie z dnia 14 czerwca 1960 r. - Kodeks postępowania administracyjnego (Dz.U. z 2013 r. poz. 267 ze zm.) oraz postępowań określonych w działach IV, V i VI Ustawy z dnia 29 sierpnia 1997 r. — Ordynacja podatkowa (Dz.U. z 2015 r. poz. 613) oraz postępowań, do których mają zastosowanie przepisy powołanych ustaw". Z kolei zgodnie z art. 71 pkt 1 Ustawy z dnia 16 listopada 2016 r. Przepisy wprowadzające ustawę o Krajowej Administracji Skarbowej (Dz.U. z 2016 r. poz. 1948) kontroli sądowoadministracyjnej podlegają inne niż decyzje i postanowienia ,akty lub czynności z zakresu administracji publicznej dotyczące uprawnień lub obowiązków wynikających z przepisów prawa, z wyłączeniem aktów lub czynności podjętych w ramach postępowania administracyjnego określonego w ustawie z dnia 14 czerwca 1960 r. - Kodeks postępowania administracyjnego (Dz.U. z 2016 r. poz. 23, 868, 996 i 1579), postępowań określonych w działach IV, V i VI Ustawy z dnia 29 sierpnia 1997 r. — Ordynacja podatkowa (Dz.U. z 2015 r. poz. 613 ze zm.), postępowań, o których mowa w dziale V w rozdziale 1 Ustawy z dnia 16 listopada 2016 r. o Krajowej Administracji Skarbowej (Dz.U. poz. 1947) oraz postępowań, do których mają zastosowanie przepisy powołanych ustaw”.

47 Por. uchwała 7 sędziów NSA z dnia 16 grudnia 2013 r., II GPS 2/13; uchwała 7 sędziów NSA z dnia 3 września 2013 r., I OPS 2/13.

48 Postanowienie NSA z dnia 14 stycznia 2009 r., II GPS 7/08.

49 Por. uchwała 7 sędziów NSA z dnia 16 grudnia 2013 r., II GPS 2/13. 
uprawnienia (obowiązku) wynikającego z przepisu prawa przez podmiot niepowiązany organizacyjnie $\mathrm{z}$ organem wydającym dany akt lub podejmującym daną czynność - związek z uprawnieniami lub obowiązkami wynikającymi z przepisów prawa musi być „ścisły" 50 ;

6) są podejmowane na podstawie przepisów prawa, które nie wymagają ich autorytatywnej konkretyzacji, lecz jedynie potwierdzenia uprawnienia lub obowiązku wynikających z przepisów powszechnie obowiązującego prawa, co oznacza również, że stanowią one przejaw wiedzy organu wykonującego administrację publiczną;

7) są podejmowane w zakresie administracji publicznej, charakteryzując się między innymi jednostronnością działania;

8) są podejmowane przez podmiot wykonujący administrację publiczną.

\section{IX}

Zestawienie doktrynalnego spojrzenia na kategorię zewnętrznych czynności materialno-technicznych $\mathrm{z}$ ujęciem tego zagadnienia w orzecznictwie sądowoadministracyjnym pozwala uchwycić ,punkty zapalne” i poddać je dalszej analizie.

Należy w pierwszej kolejności rozważyć, jakie elementy dyskwalifikują „,zewnętrzność" czynności materialno-technicznej. Jak wyżej wskazywano, z perspektywy nauki prawa administracyjnego cechą przesądzającą, że określona czynność materialno-techniczna ma charakter zewnętrzny jest to, że jest ona skierowana do adresatów niepodporządkowanych ani służbowo, ani organizacyjnie organowi dokonującemu czynności. Jeżeli czynność materialno-techniczna jest skierowana do adresatów podporządkowanych służbowo bądź organizacyjnie organowi dokonującemu czynności, to kwalifikuje się ją jako czynność wewnętrzną. Kryterium to należy zaakceptować z pewnym zastrzeżeniem dostrzeżonym w orzecznictwie. Czynność będzie miała charakter wewnętrzny, jeżeli skutek jej dokonania również nie wyjdzie poza sferę relacji wewnętrznych. Jeżeli natomiast wśród następstw tej czynności znajdą się i takie, które zmieniają status ich adresata na podmiot zewnętrzny wobec administracji publicznej, nie sposób traktować takiej czynności jako wewnętrznej. Taką właśnie koncepcję kwalifikowania określonej aktywności organu jako zewnętrznej przyjęto już kilkadziesiąt lat temu $\mathrm{w}$ orzecznictwie w sprawach administracyjnych w stosunku do indywidualnych aktów administracyjnych zmieniających status prawny ich adresata $z$ wewnętrznego na zewnętrzny lub zewnętrznego na wewnętrzny (np. w odniesieniu

50 Postanowienie NSA z dnia 4 lipca 2012 r., I OSK 1501/12; postanowienie NSA z dnia 11 grudnia 2007 r., II GSK 265/07, LEX, nr 460717. 
do wpisania i skreślenia $\mathrm{z}$ listy studentów) ${ }^{51}$. Wyrażona na tym tle w doktrynie argumentacja wskazująca, że akty prawne organów zakładu administracyjnego dotyczące sfery konstytucyjnie gwarantowanych praw i wolności jednostki są aktami administracyjnymi zewnętrznymi, a nie wewnętrznymi aktami zakładowymi w związku z konstytucyjnym zakazem zamykania drogi sądowej dochodzenia naruszonych wolności lub praw (art. 77 ust. 2 konstytucji RP) ${ }^{52}$ jest przekonująca również w przypadku czynności materialno-technicznych.

Powyższa wykładnia wypracowana w orzecznictwie w stosunku do indywidualnych aktów administracyjnych zmieniających status prawny ich adresata $\mathrm{z}$ wewnętrznego na zewnętrzny lub zewnętrznego na wewnętrzny, będąca w istocie wykładnią na rzecz prawa do sądu i stanowiąca przejaw wykładni prokonstytucyjnej, nie jest jednak przyjmowana ani w kwestii dopuszczalności zaskarżania do sądu innych niż indywidualne akty lub czynności, ani w kwestii rozumienia sformułowania „dotyczące” odnoszącego się do relacji pomiędzy czynnością a uprawnieniami lub obowiązkami wynikającymi z przepisów prawa.

Ponadto, słuszna moim zdaniem, argumentacja wskazywana w doktrynie na uzasadnienie dopuszczalności zaskarżania również aktów lub czynności o charakterze generalnym (a koncentrująca się na wykazywaniu, że brak podstaw do przypisywania aktom lub czynnościom cech właściwych decyzjom administracyjnym oraz na wskazywaniu, że struktura przepisu — dawnego art. 16 ust. 1 ustawy o NSA z 1995 roku — nie daje podstaw do przyjęcia, że najpierw wymienia on akty i czynności indywidualne, a następnie akty generalne) ${ }^{53}$ także nie została zaakceptowana w orzecznictwie, chociaż w istocie nie podważono jej zasadności ${ }^{54}$.

Z kolei wymóg, aby akty lub czynności z zakresu administracji publicznej dotyczyły uprawnień lub obowiązków wynikających z przepisów prawa, rozumiany jest w orzecznictwie jako wymóg ścisłego związku między ustaleniem, stwierdzeniem lub potwierdzeniem (oraz ich odmowami) a możliwością realizacji uprawnienia (lub obowiązku) wynikającego z przepisu prawa, przy czym nie chodzi tu o sytuacje, kiedy określone uprawnienia lub obowiązki wynikają wprost z przepisów prawa. Wskazuje się na kryterium pośredniości (bezpośredniości) wywoływania skutków prawnych i eliminuje z zakresu czynności, o jakich mowa

51 Zob. wyrok NSA z dnia 29 czerwca 1982 r., II SA 532/82, OSPiKA 1983, nr 1, poz. 20; uchwała Sądu Najwyższego z dnia 27 września 1983 r., III AZP 3/83; wyrok NSA z dnia 19 grudnia 1985 r., SA Gd 577/85, ONSA 1985, nr 2, poz. 39; postanowienie NSA z dnia 16 kwietnia 1987 r., I SA 448/87, OSPiKA 1988, nr 10, poz. 223; postanowienie NSA z dnia 12 czerwca 1992 r., SAB/ Po 41/91, LEX, nr 10816.

52 Zob. P.M. Przybysz, Kodeks postępowania administracyjnego. Komentarz, wyd. XII, Komentarz do art. 1 k.p.a., teza 16, Lex 2017.

53 Zob. J. Zimmermann, Glosa do postanowienia NSA z dnia 24 marca 1998 r., II SA 1155/97, OSP 1999, z. 9, s. 448-449.

54 Por. uchwała 7 sędziów NSA z dnia 13 października 2003 r., OPS 2003, nr 4. 
w art. $3 \S 2$ pkt 4 p.p.s.a., które podejmowane są w sytuacjach, w których treść obowiązków lub praw wynika z mocy samego prawa ${ }^{55}$.

Również ten pogląd nie wytrzymuje konfrontacji z wyżej scharakteryzowanym „dopełniającym” charakterem zewnętrznych czynności materialno-technicznych.

Działać „,bezpośrednio” to zgodnie ze znaczeniem tego pojęcia w języku polskim działać „,bez pośrednictwa kogokolwiek, czegokolwiek, wprost” ${ }^{\text {, }}$, z kolei działać w sposób „pośredni” to działać w sposób „nieodnoszący się do czegoś wprost" $"$. Należy zatem przyjąć, że charakteryzujące akty administracyjne działania, które są skierowane na wywoływanie bezpośrednio określonych skutków prawnych to takie działania, które prowadzą do ukształtowania zupełnie nowej normy, tj. normy indywidualnej i konkretnej, chociaż na podstawie normy ogólnej i abstrakcyjnej w wyniku zastosowania tej ostatniej. To wyłącznie w kompetencji organu — bez pośrednictwa kogokolwiek i czegokolwiek — pozostaje wywołanie skutku prawnego będącego następstwem normy indywidualnej i konkretnej. Etap działania organu administracji jest etapem następczym po działaniu prawodawcy, który wykreował normę ogólną i abstrakcyjną podlegającą stosowaniu i w tym znaczeniu podmioty te ze sobą nie współpracują i nie pośredniczą w dążeniu do osiągnięcia skutku prawnego w postaci wykreowania normy konkretnej i indywidualnej.

Możliwe są też sytuacje, w których bez pośrednictwa organu nie powstanie skutek prawny przewidziany w normie prawnej, mimo że norma ta nie wymaga indywidualizacji i konkretyzacji. Dzieje się to wówczas, gdy jednym z elementów stanu faktycznego, którego dotyczy określona norma ogólna i abstrakcyjna i od którego uzależnione jest uwolnienie mocy wiążącej tej normy „z samego prawa”, jest określone zachowanie organu, bez którego to zachowania nie może nastąpić skutek prawny w sferze praw i obowiązków indywidualnego podmiotu stojącego wobec administracji. W takich sytuacjach organ administracji, dopełniając swoim zachowaniem stan faktyczny, który ,uruchamia” daną normę ogólną i abstrakcyjną, jest podmiotem, który pośredniczy w wywołaniu skutku prawnego ,z mocy samego prawa", a działania organu w tym zakresie są działaniami, za pośrednictwem których możliwe jest dopiero uwolnienie skutku przewidzianego w danej normie prawnej. Takie czynności organu administracji nie będące niewątpliwie aktami administracyjnymi mają charakter zewnętrznych czynności materialno-technicznych w przyjętym wyżej rozumieniu właśnie m.in. dlatego, że pośredniczą one w uruchomieniu skutku prawnego będącego konsekwencją obowiązywania normy prawnej. Dla wykluczenia kwalifikacji danej czynności jako czynności w rozumieniu art. $3 \S 2$ pkt 4 p.p.s.a. nie jest zatem wystarczające ogólne stwierdzenie,

55 J. Drachal, J. Jagielski, R. Stankiewicz, [w:] Prawo o postępowaniu przed sądami administracyjnymi. Komentarz, red. R. Hauser, M. Wierzbowski, Warszawa 2017, s. 66.

56 Stownik współczesnego języka polskiego, red. B. Dunaj, Warszawa 1999, t. 1, s. 51.

57 Słownik współczesnego języka polskiego, red. B. Dunaj, Warszawa 1999, t. 2, s. 119. 
że określona norma kształtuje prawa lub obowiązki bezpośrednio z mocy prawa. Tylko wówczas nie mielibyśmy do czynienia z czynnościami a nawet aktami, gdyby uwolnienie mocy wiążącej normy nie było uzależnione od wcześniejszej aktywności administracji publicznej.

Uwagi powyższe pozwalają też udzielić odpowiedzi na pytanie o rozumienie użytego w art. $3 \S 2$ pkt 4 p.p.s.a. zwrotu ,czynność z zakresu administracji publicznej dotycząca uprawnień lub obowiązków wynikających z przepisów prawa". Czynność wtedy dotyczy uprawnień lub obowiązków wynikających z przepisów prawa, gdy bez tej czynności obowiązki te lub uprawnienia nie urzeczywistniają się. Nie jest przy tym istotne dla rozumienia powyższego zwrotu w jaki sposób pośrednio czy bezpośrednio - określone prawo lub obowiązek wynika z urzeczywistnianej normy, wystarczy że z tej normy po prostu wynika. Relacja mająca charakteryzować rozumienie pojęcia „dotyczy” to relacja pomiędzy czynnością organu a urzeczywistnianą normą prawną a nie kwestia sposobu wyrażenia treści urzeczywistnianej normy prawnej. Dlatego podzielić należy pogląd M. Bogusza wyrażony jeszcze na tle regulacji ustawy o NSA z 1995 roku, nazwany przez niego samego „kompromisowym”, według którego „,do istoty aktów lub czynności z zakresu administracji publicznej [...] należy to, że w sposób prawnie wiążący wpływają one na sytuację prawną określonego podmiotu prawa bądź przez to, że same tę sytuację wyznaczają, bądź przez to, że wywołują określony skutek prawny, jaki obowiązujące prawo wiąże z danym aktem lub czynnością" ${ }^{38}$.

\section{$\mathrm{X}$}

Ostatnio problem w kwalifikowaniu określonych zachowań organu z punktu widzenia podstaw ich kwalifikowania jako zewnętrzne czynności materialno-techniczne ujawnił się na tle regulacji art. 165 ust. 7 Ustawy z dnia 16 listopada 2016 roku — Przepisy wprowadzające ustawę o Krajowej Administracji Skarbowej $^{59}$ dotyczącej m.in. funkcjonariuszy służby celnej i przewidzianej w niej pisemnej propozycji określającej nowe warunki zatrudnienia albo pełnienia służby. Zgodnie z tym przepisem

dyrektor Krajowej Informacji Skarbowej, dyrektor izby administracji skarbowej oraz dyrektor Krajowej Szkoły Skarbowości składają odpowiednio pracownikom oraz funkcjonariuszom, w terminie do dnia 31 maja 2017 r., pisemną propozycję określającą nowe warunki zatrudnienia albo pełnienia służby, która uwzględnia posiadane kwalifikacje i przebieg dotychczasowej pracy lub służby, a także dotychczasowe miejsce zamieszkania.

58 M. Bogusz, op. cit., s. 182.

59 Ustawa z dnia 16 listopada 2016 r. Przepisy wprowadzające ustawę o Krajowej Administracji Skarbowej (Dz.U. z 2016 r. poz. 1948 ze zm.; dalej: u.k.a.s.). 
W niejednolitym orzecznictwie wojewódzkich sądów administracyjnych w kwestii oceny charakteru wskazanej wyżej propozycji można dostrzec stanowisko, zgodnie z którym pisemna propozycja określająca nowe warunki zatrudnienia albo pełnienia służby złożona funkcjonariuszowi na podstawie art. 165 ust. 7 u.k.a.s. stanowi czynność podlegającą zaskarżeniu do sądu administracyjnego ${ }^{60}$.

Z kolei w jednolitym do tej pory orzecznictwie Naczelnego Sądu Administracyjnego przyjęto, że powyższa pisemna propozycja określająca nowe warunki zatrudnienia albo pełnienia służby nie stanowi czynności z zakresu administracji publicznej dotyczącej uprawnień lub obowiązków wynikających z przepisów prawa $w$ rozumieniu art. $3 \S 2$ pkt 4 p.p.s.a. Reprezentatywne jest w tym zakresie stanowisko wyrażone w uzasadnieniu postanowienia NSA z dnia 18 stycznia 2018 roku, I OSK 2880/17 podzielane następnie w kilkudziesięciu kolejnych orzeczeniach tego sądu ${ }^{61}$. Zdaniem NSA

przedstawiona funkcjonariuszowi celnemu na podstawie ustawy Przepisy wprowadzające ustawę o KAS propozycja nie stanowi aktu lub czynności, o jakich mowa w art. $3 \S 2$ pkt 4 p.p.s.a. Nie dotyczy ona bowiem bezpośrednio praw i obowiązków administracyjnoprawnych wynikających z przepisów prawa, a przede wszystkim pozostaje w sferze podległości służbowej — art. 5 pkt 2 p.p.s.a. Stosownie do powołanego przepisu sądy administracyjne nie są właściwe w sprawach wynikających z podległości służbowej między przełożonymi i podwładnymi. W analizowanym przypadku organ przedkładający propozycję występuje w charakterze pracodawcy, a nie jako organ administracji publicznej. Propozycja nowych warunków zatrudnienia lub służby stanowi jedynie ofertę będącą elementem szerszego procesu zmierzającego do pozostawienia funkcjonariusza w stosunku zatrudnienia. Sama propozycja nie kształtuje ostatecznie sytuacji prawnej funkcjonariusza, sama przez się nie zmienia dotychczasowej sytuacji. Sytuacja ta ulega zmianie dopiero z chwilą zajęcia przez funkcjonariusza stanowiska w przedmiocie przedłożonej propozycji. Tym samym propozycja o jakiej mowa w art. 165 ust. 7 ustawy Przepisy wprowadzające ustawę o KAS nie stanowi czynności w rozumieniu art. $3 \S 2$ pkt 4 p.p.s.a., co oznacza że skarga funkcjonariusza celnego na propozycję określającą nowe warunki zatrudnienia albo pełnienia służby jest niedopuszczalna.

Stanowisko powyższe trudno zaakceptować.

Mając na uwadze przedstawione wyżej rozważania teoretyczne, należy zwrócić uwagę na te spostrzeżenia, które są pomocne w odczytaniu treści art. 165 ust. 7 u.k.a.s. Jak zatem wynika z tych rozważań, jedną z cech odróżniającą czynność z zakresu administracji publicznej dotyczącą uprawnień lub obowiązków wynikających z przepisów prawa od aktów administracyjnych jest to, że czynności są działaniami faktycznymi, tj. działaniami ukierunkowanymi na wywołanie skutków prawnych jako następstw zaistnienia określonych faktów. Czynności te „uruchamiają" następstwa prawne przewidziane w normach obowiązującego prawa,

60 Wyrok WSA w Krakowie z dnia 23 listopada 2017 r., III SA/Kr 1040/17; wyrok WSA w Krakowie z dnia 27 listopada 2017 r., III SA/Kr 900/17; wyrok WSA w Krakowie z dnia 29 listopada 2017 r., III SA/Kr 980/17; wyrok WSA w Krakowie z dnia 5 grudnia 2017 r., III SA/Kr 983/17.

61 Zob. np. postanowienia NSA: z dnia 23 stycznia 2018 r., I OSK 2805/17; z dnia 24 stycznia 2018 r., I OSK 2827/17; z dnia 25 stycznia 2018 r., I OSK 2856/17; z dnia 6 lutego 2018 r., I OSK 2955/17; z dnia 8 lutego 2018 r., I OSK 3001/17; z dnia 9 lutego 2018 r., I OSK 2904/17; z dnia 20 lutego 2018 r., I OSK 2936/17. 
stanowiąc elementy stanów faktycznych objętych hipotezami norm prawa administracyjnego. Od zaistnienia tych stanów faktycznych uzależnione jest działanie „Z mocy prawa” tego rodzaju norm. Z kolei brak zaistnienia określonych faktów sprawia, że norma prawna powiązana $z$ tymi faktami nie wywołuje przewidzianych w niej skutków. Innymi słowy czynność w rozumieniu art. $3 \S 2$ pkt 4 p.p.s.a. wywołuje skutek przewidziany w normach obowiązującego prawa, które nie wymagają indywidualizacji i konkretyzacji w drodze aktu administracyjnego. O ile więc akt administracyjny jest działaniem prawnym stanowiącym konkretyzację i indywidualizację ogólnej i abstrakcyjnej normy materialnego prawa administracyjnego, o tyle czynność stanowi fakt uruchomiający skutek w postaci działania normy prawa administracyjnego „z mocy samego prawa”. Ta specyfika czynności w rozumieniu art. $3 \S 2$ pkt 4 p.p.s.a. sprawia, że ustawodawca wyposażył sąd administracyjny w kompetencję do stwierdzania bezskuteczności czynności, a nie do ich uchylania, jak to ma miejsce w przypadku aktów, o których mowa w tym przepisie (art. 147 § 1 p.p.s.a.). Stwierdzenie bezskuteczności oznacza deklarację, że określona czynność nie uruchomiła skutków prawnych, na które była ukierunkowana.

Analiza przepisów u.k.a.s. wykazuje, że pisemna propozycja określająca nowe warunki zatrudnienia albo pełnienia służby składana w trybie art. 165 ust. 7 tej ustawy ukierunkowana jest w sposób bezpośredni na zachowanie bądź zakończenie stosunków służbowych funkcjonariuszy, do których jest kierowana, a zatem niewątpliwie dotyczy sfery ich praw i obowiązków wynikających z przepisów prawa.

Należy zwrócić uwagę, że z brzmienia art. 170 ust. 1 pkt 1 u.k.a.s. wynika, że skutek w postaci wygaśnięcia stosunku służbowego uzależniony jest od zaistnienia określonych faktów, wśród których zasadniczym faktem jest złożenie przez dyrektora Krajowej Informacji Skarbowej, dyrektora izby administracji skarbowej oraz dyrektora Krajowej Szkoły Skarbowości odpowiednio pracownikom oraz funkcjonariuszom, w terminie do dnia 31 maja 2017 roku, pisemnej propozycji określającej nowe warunki zatrudnienia albo pełnienia służby. Z redakcji przepisu art. 165 ust. 7 u.k.a.s. wynika kompetencja wskazanych wyżej organów Krajowej Administracji Skarbowej do złożenia powyższej propozycji, przy czym kategoryczne brzmienie przepisu, w którym użyto zwrotu „składa”, a nie „może złożyć” pisemną propozycję, wskazuje, że złożenie pisemnej propozycji określającej nowe warunki zatrudnienia albo pełnienia służby jest obowiązkiem powyższych organów. Jednocześnie ustawodawca wprowadził ramy czasowe skorzystania z tej kompetencji wskazując, że wyżej wymienione organy składają pisemną propozycję określającą nowe warunki zatrudnienia albo pełnienia służby w terminie do dnia 31 maja 2017 roku. Termin, który kształtuje ramy czasowe realizowania kompetencji, ma charakter terminu prawa materialnego, co powoduje, że z upływem tego terminu kompetencja ta nie może być już skutecznie prawnie realizowana, a w konsekwencji czynność dokonana po 
tym terminie, nie jest zdolna do wywołania skutku prawnego. Nie ma żadnych podstaw do przypisywania ustawodawcy intencji uzależniania skutków prawnych dotyczących sfery praw i obowiązków obywateli, w tym przypadku w zakresie trwania dotychczasowego stosunku służbowego, od nierealizowania ustawowych kompetencji organów administracji publicznej, którym to organom ustawodawca wyznaczył określony termin na podjęcie określonych czynności. Wszystko to prowadzi do wniosku, zgodnie z którym niezrealizowanie przez organy ciążącego na nich obowiązku przedstawienia w ustawowym terminie pisemnej propozycji określającej nowe warunki zatrudnienia albo pełnienia służby powoduje, że nie aktualizuje się skutek prawny w postaci wygaśnięcia dotychczasowego stosunku służbowego. Warunkiem koniecznym — chociaż nie jedynym — zaistnienia skutku prawnego w postaci wygaśnięcia dotychczasowego stosunku służbowego jest złożenie w ustawowym terminie pisemnej propozycji określającej nowe warunki zatrudnienia albo pełnienia służby.

Drugim elementem stanu faktycznego - możliwym do rozważania dopiero w przypadku wykonania przez organy w ustawowym terminie obowiązku złożenia pisemnej propozycji określającej nowe warunki zatrudnienia albo pełnienia służby — od którego uzależniony jest skutek w postaci wygaśnięcia z mocy prawa stosunku służbowego jest „nieotrzymanie w terminie do dnia 31 maja 2017 r.” przez funkcjonariusza pisemnej propozycji określającej nowe warunki zatrudnienia albo pełnienia służby (art. 171 ust. 1 pkt 1 u.k.a.s.).

Przyjęte w języku polskim rozumienie pojęcia „otrzymać” oznacza „stawanie się odbiorcą jakiejś rzeczy; dostawanie czegoś, odbieranie czegoś" ${ }^{\prime \prime 2}$. Pojęcie to związane jest zatem z zachowaniem adresata określonego działania. Wykładnia systemowa u.k.a.s. potwierdza rezultat wykładni językowej i pozwala przyjąć, że ustawodawca „otrzymanie propozycji” wiąże z faktem jej skutecznego dojścia do adresata. $\mathrm{W}$ treści przepisu art. 169 ust. 1 u.k.a.s. ustawodawca również posługuje się terminem „otrzymania” przez funkcjonariusza propozycji, wskazując jednocześnie w art. 169 ust. 4 u.k.a.s., że „,w terminie 14 dni od dnia przyjęcia propozycji przysługuje wniosek o ponowne rozpatrzenie sprawy", przy czym w tym przypadku chodzi o mającą formę decyzji administracyjnej propozycję pełnienia służby w Służbie Celno-Skarbowej, a do postępowań w tych sprawach stosuje się przepisy k.p.a. (art. 169 ust. 6), które m.in. zawierają unormowania dotyczące doręczania pism procesowych, przewidując skutek doręczenia nawet w sytuacjach, gdy adresat uchyla się od odbioru pisma. Nie ma podstaw, aby pojęcie „otrzymania propozycji” rozumieć inaczej na gruncie regulacji przepisu art. 170 ust. 1 pkt 1 u.k.a.s. Otrzymanie pisemnej propozycji to zatem przyjęcie przez adresata tej propozycji pisma, w którym propozycję tę zawarto, tożsame ze skutecznym jego doręczeniem. „Otrzymanie" pisemnej propozycji w terminie do dnia 31 maja 2017 roku może mieć zatem miejsce wtedy, gdy po pierwsze organ wypełnił obowiązek złożenia

62 Por. Stownik..., t. 1, s. 700. 
takiej propozycji wobec pracownika lub funkcjonariusza, a po drugie pracownik ten lub funkcjonariusz w takiej sytuacji stał się w sposób skuteczny prawnie odbiorcą pisma zawierającego propozycję. Zweryfikowanie powyższej wykładni rezultatami wykładni celowościowej prowadzi do wniosku, że w przypadku zrealizowania przez organ jego obowiązku złożenia pisemnej propozycji określającej nowe warunki zatrudnienia albo pełnienia służby, jej adresat nie powinien mieć możliwości - poprzez uchylanie się od odbioru pisma zawierającego tę propozycję - wyeliminowania ustawowego skutku wygaśnięcia stosunku służbowego. Skoro ustawodawca z faktem ,nieotrzymania” pisemnej propozycji w określonym terminie wiąże skutek prawny w postaci ukształtowania sfery praw i obowiązków funkcjonariusza lub pracownika, do czego prowadzi wygaśnięcie stosunku służbowego, to brak podstaw do przypisywania ustawodawcy intencji wiązania tego skutku z takimi okolicznościami, jak nierealizowanie obowiązków przez organy administracji publicznej bądź uzależniania tego skutku od przypadku (np. zaginięcia pisma z propozycją) czy działania osób trzecich (np. zagubienia pisma przez posłańca). Dopiero wiązanie skutku prawnego w postaci wygaśnięcia stosunku służbowego funkcjonariusza z wypełnieniem przez organy ich ustawowych obowiązków z jednej strony (złożenie w ustawowym terminie pisemnej propozycji nowych warunków zatrudnienia lub pełnienia służby) oraz interpretacją eliminującą unikanie skutków prawnych złożonej propozycji przez osoby, do których ją skierowano, pozwala zachować spójność omawianych regulacji i ich zgodność z konstytucyjnymi standardami demokratycznego państwa prawa, według których ingerencja $\mathrm{w}$ sferę praw i obowiązków obywateli powinna znajdować wyraźną podstawę ustawową, a adresaci działań administracji publicznej nie powinni ponosić konsekwencji jej zaniedbań.

Wszystkie powyższe spostrzeżenia prowadzą do wniosku, że pisemna propozycja określająca nowe warunki zatrudnienia albo pełnienia służby składana w trybie art. 165 ust. 7 u.k.a.s. stanowi czynność z zakresu administracji publicznej dotyczącą uprawnień lub obowiązków wynikających z przepisów prawa w rozumieniu art. $3 \S 2$ pkt 4 p.p.s.a. Jest to bowiem czynność dokonywana przez organy administracji publicznej, stanowiąca warunek konieczny wywołania skutku wygaśnięcia stosunku pracy z mocy samego prawa, a zatem skutku wykraczającego poza relacje wewnętrzne, skoro skutek ten stawia adresata propozycji poza służbą, a w konsekwencji dotycząca uprawnień lub obowiązków wynikających z przepisów prawa. Czynność ta powinna zatem podlegać skardze do sądu administracyjnego, którego obowiązkiem jest jej skontrolowanie przy ocenie prawidłowości zastosowania przez organ kryteriów określonych w art. 165 ust. 7 u.k.a.s. Fakt posłużenia się przez ustawodawcę w konstrukcji tych kryteriów pojęciami ogólnymi i ocennymi nie wyklucza pełnej kontroli legalności powyższej czynności, zgodnie bowiem z ugruntowanymi poglądami orzecznictwa wykładnia przepisów, w których posłużono się nawet zwrotami nieokreślonymi, podlega pełnej kontroli sądowoadministracyjnej, a działania organów stanowiące podstawę do ingerencji 
w sferę praw i obowiązków obywateli — zwłaszcza sferę praw nabytych — wymagają szczegółowego uzasadnienia wykazującego zasadność tego rodzaju działań w odniesieniu do indywidualnie oznaczonego adresata w konkretnej sytuacji faktycznej i prawnej.

Powyższe uwagi korespondują z przytaczanymi już w tym opracowaniu głosami doktryny i orzecznictwa, zgodnie z którymi z istoty zewnętrznych czynności materialno-technicznych jako działań właśnie zewnętrznych i objętych swojego rodzaju domniemaniem na ich rzecz wynika, że powinny one podlegać kontroli sądowoadministracyjnej stanowiącej wyraz realizacji konstytucyjnego prawa do sądu ${ }^{63}$.

Standard ten może być zapewniony poprzez kontrolę bezpośrednią, tj. następującą na skutek skarg składanych na tego rodzaju czynności, jak i przez kontrolę pośrednią, która ma miejsce wtedy, gdy przedmiotem kontroli sądowej nie jest bezpośrednio czynność materialno-techniczna, lecz np. odmowa podjęcia takiej czynności, która zazwyczaj przebiera formę decyzji administracyjnej — „kontrola działań faktycznych jest wtedy dokonywana niejako »przy okazji« kontroli aktów administracyjnych"64. Jak jednak zauważa E. Łętowska w ramach rozważań nad wykorzystywaniem możliwości, jakie dawała regulacja art. 16 ust. 1 pkt 4 ustawy o NSA z 1995 roku (będąca ,poprzedniczką” obecnej regulacji z art. 3 § 2 pkt 4 p.p.s.a.): „NSA z właściwym każdemu sądowi oportunizmem (in dubio contra iudici activitatem) w wypadku zjawisk niemieszczących się w głównym nurcie znanych rutyn skłonny jest raczej powołać się na brak własnej kognicji, niż wykorzystać subsydiarną podstawę dla jej realizacji”" ${ }^{25}$.

\section{Bibliografia}

Adamiak B., glosa do wyroku NSA z dnia 19 maja 2003 r., OSA 1/03, OSP 2003, nr 11, poz. 136. Adamiak B., Zagadnienie domniemania formy decyzji administracyjnej, [w:] Podmioty administracji publicznej i prawne formy ich działania. Studia i materiaty z Konferencji Naukowej poświęconej Jubileuszowi 80-tych urodzin Profesora Eugeniusza Ochendowskiego, Torun 2005.

Adamiak B., Borkowski J., Polskie postepowanie administracyjne i sądowoadministracyjne, Warszawa 1996.

63 M. Masternak, Kontrola czynności..., s. 131.

64 A. Mituś, Działania faktyczne administracji publicznej a zasada legalizmu - zarys problematyki, [w:] Teoria instytucji prawa administracyjnego. Księga pamiatkowa Profesora Jerzego Stefana Langroda, red. J. Niczyporuk, Paryż 2011, s. 353.

65 E. Łętowska, glosa do wyroku NSA z dnia 14 sierpnia 2002 r., II SA/Gd 4182/01, OSP 2003, nr 10, poz. 135. 
Błaś A., Formy działań faktycznych, [w:] Prawo administracyjne, red. J. Boć, Wrocław 2004.

Bogusz M., Pojęcie aktów lub czynności z zakresu administracji publicznej dotyczacych przyznania, stwierdzenia albo uznania uprawnienia lub obowiazku, wynikajacych z przepisów prawa w rozumieniu art. 16 ust. 1 pkt 4 ustawy o NSA, ,Samorząd Terytorialny” 2000, nr 1-2.

Borkowski J., Podmiot uprawniony do wniesienia skargi do sądu administracyjnego w świetle ustawy o Naczelnym Sądzie Administracyjnym, „Samorząd Terytorialny” 1997, nr 5.

Drachal J., Jagielski J., Stankiewicz R., [w:] Prawo o postępowaniu przed sadami administracyjnymi. Komentarz, red. R. Hauser, M. Wierzbowski, Warszawa 2017.

Jakimowicz W., Problem definiowania pojęcia decyzji administracyjnej, „Przegląd Sądowy” 2000, nr 10.

Jakimowicz W., Publiczne prawa podmiotowe, Kraków 2002.

Jendrośka J., Adamiak B., glosa do wyroku NSA z dnia 27 kwietnia 1981 r., SA 767/81, OSP 1983, nr 5, poz. 109.

Kmieciak Z., Czynności faktyczne administracji państwowej, „Studia Prawno-Ekonomiczne” 1987, t. 39.

Łętowska E., Glosa do wyroku NSA z dnia 29 maja 2003 r., II SAB 419/02, OSP z 2004 r., nr 7-8, poz. 90.

Łętowski J., Prawo administracyjne. Zagadnienia podstawowe, Warszawa 1990.

Masternak M., Kontrola czynności materialno-technicznych administracji publicznej przez sąd administracyjny, [w:] Prawo do dobrej administracji, red. Z. Niewiadomski, Z. Cieślak, Warszawa 2003.

Masternak-Kubiak M., Glosa do postanowienia NSA z dnia 16 września 2004 r., OSK 250/04, „Przegląd Sejmowy” 2005, nr 1.

Mituś A., Działania faktyczne administracji publicznej a zasada legalizmu — zarys problematyki, [w:] Teoria instytucji prawa administracyjnego. Ksiega pamiątkowa Profesora Jerzego Stefana Langroda, red. J. Niczyporuk, Paryż 2011.

Przybysz P.M., Kodeks postępowania administracyjnego. Komentarz, wyd. XII, Komentarz do art. 1 k.p.a., Lex 2017.

Stownik współczesnego języka polskiego, red. B. Dunaj, Warszawa 1999.

Stahl M., Czynności materialno-techniczne, [w:] Prawo administracyjne. Pojęcia, instytucje, zasady w teorii i orzecznictwie, red. M. Stahl, Warszawa 2016,

Starościak J., Prawne formy działania administracji, Warszawa 1957.

Wierzbowski M., Wiktorowska A., Czynności faktyczne, [w:] Polskie prawo administracyjne, red. J. Służewski, Warszawa 1995.

Woś T., Postępowanie sądowoadministracyjne, Warszawa 1996.

Zawadzki S., Świątkiewicz J., Z doświadczeń NSA, „Państwo i Prawo” 1981, nr 6.

Ziemski K.M., Formy prawne realizacji materialnego prawa administracyjnego, [w:] Rola materialnego prawa administracyjnego a ochrona praw jednostki, red. Z. Leoński, Poznań 1998.

Ziemski K.M., Indywidualny akt administracyjny jako forma prawna działania administracji, Poznań 2005.

Zimmermann J., Glosa do postanowienia NSA z dnia 24 marca 1998 r., II SA 1155/97, OSP z 1999 r., nr 9, poz. 164.

Zimmermann J., Polska jurysdykcja administracyjna, Warszawa 1996.

Zimmermann J., Prawo administracyjne, Warszawa 2018.

Zimmermann M., Formy działania administracji państwowej. Akt administracyjny, [w:] M. Jaroszyński, M. Zimmermann, W. Brzeziński, Polskie prawo administracyjne. Czesść ogólna, Warszawa 1956. 


\title{
External factual activities of public administration
}

\begin{abstract}
Summary
The considerations within the article have been devoted to external factual activities which, unlike internal factual activities, are directed to addressees which are not formally or organizationally subordinated. These can be activities that — as forms of action — are independent, as well as those that to some extent involve other forms of action, for example, acting to "complement" direct-obliging actions by releasing the binding force of norms resulting from this kind of activities.
\end{abstract}

Keywords: factual activities, forms of administrative actions, external activities. 